RESEARCH ARTICLE

\title{
Influence of Different Organic Manures on Growth, Yield Components and Productivity of Cotton
}

\author{
Subramanian $\mathrm{E}^{1^{*}}$, Sathishkumar $\mathrm{A}^{1}$ and Rajesh $\mathrm{P}^{2}$ \\ ${ }^{1}$ Department of Agronomy, Agricultural College and Research Institute, Madurai - 625104 \\ ${ }^{2}$ Department of Crop Management, RVS Agricultural College, Thanjavur - 613402
}

Received : $20^{\text {th }}$ November, 2020

Revised : $28^{\text {th }}$ November, 2020

Revised : $11^{\text {th }}$ December, 2020

Accepted : $18^{\text {th }}$ December, 2020

\section{ABSTRACT}

The present study aimed to the effect of different organic manures on the growth and yield attributes of cotton by conducting field experiments during rice fallow season of 2013-14 and 2014-15 at the Tamil Nadu Rice Research Institute, Aduthurai. The cotton growth parameters such as plant height, leaf area index, dry matter production and monopodial branches plant ${ }^{-1}$ were significantly influenced by the application of $100 \%$ recommended dose of fertilizer through vermicompost (on equal $\mathrm{N}$ basis). Also application of recommended dose of fertilizer through vermicompost (on equal $\mathrm{N}$ basis) recorded significantly higher yield attributes viz., sympodial branches plant ${ }^{1}$, number of bolls plant ${ }^{-1}$, boll weight and seed cotton yield (17.4 and 18.6 q ha-1 during both the years, respectively). Economic analysis also indicated that Insitu vermicomposting produced higher net returns with higher B:C ratio.

Keywords: Organic manures; Vermicompost; Growth attributes; Seed cotton yield; Economics

\section{INTRODUCTION}

The crop, cotton is known as the "king of fibres" continues to be the predominant fibre in the Indian textile scene, despite stiff competition by the manmade synthetic fibres. It assumes a place of pride in the Indian economy, as cotton production, processing and trade in cotton goods provide employment to millions of people in our country. Further, the export of raw cotton, yarn, textile, garments, cotton seed cake, oil and other by-products earns valuable foreign exchange. Organic farming is a production system that avoids or largely excludes the use of synthetically compounded fertilizers, pesticides, growth regulators and livestock feed additives. Modern agriculture based on chemicals is not sustainable because of many problems such as loss of soil productivity from excessive erosion and associated plant nutrient losses, surface and ground water pollution from pesticides, fertilizers and sediments, impending shortages of non-renewable resources and low farm income from high production costs. As a result, there is increasing awareness of the need for alternative agricultural systems. Although chemical fertilizers are playing a crucial role in meeting the nutrient requirement of the crop, persistent nutrient depletion is posing a greater threat to sustainable agriculture. Therefore, there is an urgent need to reduce the usage of chemical fertilizers and in turn increase the usage of organics. The use of organic manures alone or in combination with chemical fertilizers helps in improving physicochemical properties of the soil and improves the efficient utilization of applied fertilizers resulted in higher seed yield and quality. Organic manures viz., farm yard manure, vermicompost, poultry manure and oilcakes help in the improvement of soil structure, aeration and water holding capacity of soil. Further, it stimulates the activity of microorganisms that makes the plant to get the macro and micro-nutrients through enhanced biological processes, increase nutrient solubility, alter soil salinity, sodicity and $\mathrm{pH}$ (Alabadan et al., 2009). Though they contain relatively low concentrations of nutrients and handling them is labor intensive, there has been a large increase in their use of inorganic fertilizers as nutrient source (Kannan et al., 2005). Green manuring is a cheap alternative to the use of fertilizer nitrogen. The process also makes a positive contribution to the maintenance of soil organic matter content at a satisfactory level. Green manuring is a low-cost but effective technology in minimizing investment cost on fertilizers and in safeguarding the production capacity of the soil without any impoverishment. Leguminous green manures have the ability to utilize insoluble phosphates through the well-developed root system, and upon mineralization, release the $P$ in the available forms. Green manuring is a practice of turning green biomass in the soil to improve physical, physicochemical as well as biological properties suitable for plant growth. It is a convenient

$$
107 \mid 10-12 \text { | } 400
$$


means to furnish higher amount of nitrogen to the beneficiary crops. Therefore, the soil must be 'fed' in a way that the beneficial soil organisms necessary for recycling nutrients and producing humus are not inhibited. The long-term manurial studies conducted at many places have revealed the superiority of integrated nutrient supply systems in sustaining crop productivity in comparison to chemical fertilizer alone (Gaur, 1991). Hence, the present investigation was carried out to study the effect of various types of organic manures on the growth and yield of cotton.

\section{MATERIAL AND METHODS}

Field experiments were conducted during the rice fallow season of 2013-14 and 2014-15 at Tamil Nadu Rice Research Institute, Aduthurai, during rice fallow season (December - April). The experiment was laid out in randomised block design with three replications, consisting of 16 treatments viz., $T_{1}$ Control (No fertilizer / Manures), $T_{2}-100 \%$ RDF (Recommended dose of fertilizer) through FYM (Farm yard manure) (on equal $\mathrm{N}$ basis), $\mathrm{T}_{3}-100 \%$ RDF through Vermicompost (on equal $\mathrm{N}$ basis), $\mathrm{T}_{4}-100 \%$ RDF through Poultry Manure (on equal $\mathrm{N}$ basis) , $\mathrm{T}_{5}-100 \%$ RDF through Tricho compost (on equal $\mathrm{N}$ basis), $\mathrm{T}_{6}-50 \%$ RDF through FYM + 50\% RDF through Vermicompost, $\mathrm{T}_{7}-50 \%$ RDF through FYM + 50\% RDF through Poultry Manure, $\mathrm{T}_{8}$ - 50\% RDF through FYM + 50\% RDF through Tricho Compost, $\mathrm{T}_{9}-50 \%$ RDF through Vermicompost + $50 \%$ RDF through Poultry Manure, $\mathrm{T}_{10}-50 \%$ RDF through Vermicompost $+50 \%$ RDF through Tricho Compost, $\mathrm{T}_{11}-50 \%$ RDF through Poultry Manure $+50 \%$ RDF through Tricho Compost, $T_{12}-1 / 4^{\text {th }}$ FYM $+1 / 4^{\text {th }}$ Vermicompost $+1 / 4^{\text {th }}$ Poultry Manure
$+1 / 4^{\text {th }}$ Tricho Compost, $T_{13}$ Intercropping Green Manure with Sunnhemp and in situ incorporation on 50\% flowering + 50\% RDF through $\mathrm{FYM}, \mathrm{T}_{14}{ }^{-}$ Intercropping Green Manure with Sunnhemp and in situ incorporation on 50\% flowering + 50\% RDF Vermicompost, $\mathrm{T}_{15}$-Intercropping Green Manure with Sunnhemp and in situ incorporation on 50\% flowering $+50 \%$ RDF through Poultry Manure and $\mathrm{T}_{16}$-Intercropping Green Manure with Sunnhemp and in situ incorporation on 50\% flowering + 50\% RDF through Tricho Compost. The soil of the experimental site was clay loam in texture and $\mathrm{pH}$ was normal (7.2). The soil was low in available nitrogen (211 kg ha-1), high in available phosphorus (26 kg ha-1) and medium in available potassium (180 kg ha-1). The organic carbon content was medium $(0.59 \%)$ in range. MCU7 cotton variety was used as a test crop. The cotton seed was line sown with the spacing of $60 \times 30 \mathrm{~cm}$. Different growth attributes viz., plant height, leaf area index, dry matter production and number of monopodial branches plant ${ }^{-1}$ and yield contributing characters like number of sympodial branches plant ${ }^{-1}$, number of bolls plant ${ }^{-1}$ and boll weight of cotton were studied during the field investigation. Data on different aspects of crop were subjected to statistical analysis as per the procedure of Randomized Block Design.

\section{RESULTS AND DISCUSSION}

\section{Growth attributes of cotton}

Different organic manure treatments had significant influence on the growth attributes of cotton, such as plant height, leaf area index, dry matter production and number of monopodial branches plant ${ }^{-1}$ (Table 1 ).

Table 1. Growth attributes of cotton under different organic nutrient management practices.

\begin{tabular}{|c|c|c|c|c|c|c|c|c|c|c|}
\hline \multicolumn{6}{|c|}{ 2013-14 } & \multicolumn{5}{|c|}{ 2014-15 } \\
\hline \multirow{2}{*}{ Treatment } & \multirow{2}{*}{$\begin{array}{l}\text { Plant } \\
\text { height } \\
(\mathrm{cm}) \\
\text { At } \\
\text { harvest }\end{array}$} & \multicolumn{2}{|c|}{ CGR ( $\left(\mathrm{g} \mathrm{m}^{-2}\right.$ day $\left.^{-1}\right)$} & \multirow{2}{*}{$\begin{array}{l}\text { LAI at } \\
\text { flowering }\end{array}$} & \multirow{2}{*}{$\begin{array}{l}\text { DMP at } \\
\text { harvest } \\
\left(\mathrm{kg} \mathrm{ha}^{-1}\right)\end{array}$} & \multirow{2}{*}{$\begin{array}{c}\text { Plant } \\
\text { height } \\
(\mathrm{cm})\end{array}$} & \multicolumn{2}{|c|}{ CGR $\left(\mathrm{g} \mathrm{m}^{-2}\right.$ day $\left.^{-1}\right)$} & \multirow{2}{*}{$\begin{array}{c}\text { LAI } \\
\text { at } \\
\text { flowering }\end{array}$} & \multirow{2}{*}{$\begin{array}{c}\text { DMP } \\
\text { at } \\
\text { harvest } \\
\left(\mathrm{kg} \mathrm{ha}^{-1}\right)\end{array}$} \\
\hline & & $30-60$ DAS & 60-120 DAS & & & & $30-60$ DAS & 60-120 DAS & & \\
\hline$T_{1}$ & 86.8 & 3.71 & 2.89 & 2.45 & 2759 & 94.6 & 4.00 & 2.82 & 3.31 & 3090 \\
\hline $\mathrm{T}_{2}$ & 112.9 & 3.73 & 3.94 & 2.63 & 2875 & 123.1 & 4.27 & 2.89 & 4.18 & 3220 \\
\hline $\mathrm{T}_{3}$ & 115.3 & 5.58 & 4.02 & 3.54 & 4064 & 124.7 & 6.22 & 3.84 & 4.31 & 4421 \\
\hline $\mathrm{T}_{4}$ & 108.5 & 5.23 & 3.54 & 3.16 & 3702 & 118.3 & 6.15 & 3.43 & 3.68 & 4146 \\
\hline $\mathrm{T}_{5}$ & 106.9 & 4.91 & 3.89 & 3.21 & 3619 & 116.5 & 6.17 & 3.28 & 4.05 & 4053 \\
\hline $\mathrm{T}_{6}$ & 102.1 & 4.47 & 3.95 & 3.09 & 3402 & 110.3 & 4.97 & 3.50 & 4.09 & 3810 \\
\hline $\mathrm{T}_{7}$ & 100.6 & 4.01 & 3.96 & 3.21 & 3329 & 109.7 & 5.29 & 3.21 & 4.12 & 3728 \\
\hline $\mathrm{T}_{8}$ & 107.5 & 5.20 & 3.79 & 3.10 & 3640 & 117.2 & 5.37 & 3.57 & 3.94 & 3982 \\
\hline $\mathrm{T}_{9}$ & 107.3 & 3.84 & 4.03 & 3.04 & 3174 & 114.2 & 4.60 & 3.28 & 4.19 & 3555 \\
\hline$T_{10}$ & 102.2 & 3.82 & 3.62 & 2.99 & 3133 & 111.4 & 4.57 & 3.22 & 3.76 & 3509 \\
\hline $\mathrm{T}_{11}$ & 99.8 & 3.69 & 3.77 & 2.55 & 2823 & 108.8 & 3.99 & 2.94 & 3.98 & 3162 \\
\hline $\mathrm{T}_{12}$ & 114.2 & 5.62 & 3.08 & 3.49 & 4033 & 126.5 & 6.49 & 3.94 & 4.25 & 4517 \\
\hline $\mathrm{T}_{13}$ & 108.4 & 5.20 & 3.56 & 3.17 & 3691 & 118.2 & 6.11 & 3.40 & 3.70 & 4134 \\
\hline $\mathrm{T}_{14}$ & 105.8 & 4.61 & 3.66 & 3.23 & 3536 & 115.3 & 5.82 & 3.28 & 3.81 & 3960 \\
\hline $\mathrm{T}_{15}$ & 99.7 & 3.92 & 3.43 & 3.18 & 3288 & 108.7 & 4.59 & 3.47 & 3.57 & 3683 \\
\hline $\mathrm{T}_{16}$ & 100.6 & 4.30 & 3.37 & 3.09 & 3350 & 109.7 & 4.93 & 3.44 & 3.50 & 3752 \\
\hline $\begin{array}{l}C D \\
(p=0.05 \%)\end{array}$ & 6.6 & 1.20 & 0.59 & 0.79 & 396 & 6.8 & 1.38 & 0.81 & 0.31 & 432 \\
\hline
\end{tabular}


At 30 days after sowing (DAS), application of $50 \%$ RDF through vermicompost $+50 \%$ RDF through tricho compost produced the tallest plant of $17.9 \mathrm{~cm}$. However, this was comparable with the application of $100 \%$ RDF through tricho compost (on equal $\mathrm{N}$ basis), 50\% RDF through FYM + 50\% RDF through poultry manure, 50\% RDF through FYM + 50\% RDF through vermicompost, 50\% RDF through poultry manure $+50 \%$ RDF through tricho compost, intercropping green manure with sunnhemp and in situ incorporation on 50\% flowering $+50 \%$ RDF through FYM and 100\% RDF through poultry manure (on equal $\mathrm{N}$ basis). However, at later stages of plant growth, application of 100\% RDF through vermicompost (on equal $\mathrm{N}$ basis) produced taller plant and it was significantly comparable with $1 / 4^{\text {th }}$
$\mathrm{FYM}+1 / 4^{\text {th }}$ vermicompost $+1 / 4^{\text {th }}$ poultry manure + $1 / 4^{\text {th }}$ tricho compost, and $100 \%$ RDF through FYM (on equal $\mathrm{N}$ basis). This might be due to availability of nutrients from organic sources and favourable conditions created in uptake of plant nutrients by the crop (Chavda and Rajawat, 2015). The plant growth is the function of photosynthetic activity of the plants and translocation of photosynthates within the plant which ultimately depend on their capacity to utilize available nutrients. Later boost of nitrogen which might have helped in higher chlorophyll formation and ultimately higher photosynthesis, resulted in more plant height. Nitrogen is also known to contribute to cell elongation. These results are in conformity with results obtained by Chandramohan and Chandaragiri (2007).

Table 2. Yield attributes and seed yield of cotton under different organic nutrient management practices

\begin{tabular}{|c|c|c|c|c|c|c|c|c|c|c|}
\hline \multicolumn{6}{|c|}{ 2013-14 } & \multicolumn{5}{|c|}{ 2014-15 } \\
\hline Treatment & $\begin{array}{r}\text { Monopodial } \\
\text { branches } \\
\text { plant }^{-1}\end{array}$ & $\begin{array}{r}\text { Sympodial } \\
\text { branches } \\
\text { plant }^{-1}\end{array}$ & $\begin{array}{r}\text { No. of } \\
\text { bolls } \\
\text { plant }^{-1}\end{array}$ & $\begin{array}{r}\text { Boll } \\
\text { weight } \\
\text { (g) }\end{array}$ & $\begin{array}{r}\text { Seed cotton } \\
\text { yield }(\mathrm{q} \\
\left.\mathrm{ha}^{-1}\right)\end{array}$ & $\begin{array}{r}\text { Monopodial } \\
\text { branches }^{-1} \text { plant }^{-1}\end{array}$ & $\begin{array}{r}\text { Sympodial } \\
\text { branches } \\
\text { plant }^{-1}\end{array}$ & $\begin{array}{r}\text { No. of } \\
\text { bolls } \\
\text { plant }^{-1}\end{array}$ & $\begin{array}{r}\text { Boll } \\
\text { weight } \\
\text { (g) }\end{array}$ & $\begin{array}{r}\text { Seed } \\
\text { cotton } \\
\text { yield } \\
\left.(\mathrm{q} \mathrm{ha})^{-1}\right)\end{array}$ \\
\hline $\mathrm{T}_{1}$ & 5.95 & 11.97 & 15.4 & 2.67 & 7.42 & 6.94 & 13.2 & 14.6 & 2.98 & 8.57 \\
\hline $\mathrm{T}_{2}$ & 4.11 & 14.77 & 23.6 & 2.78 & 11.37 & 4.93 & 15.5 & 23.8 & 3.03 & 11.8 \\
\hline$T_{3}$ & 4.23 & 15.32 & 24.5 & 3.93 & 17.84 & 5.12 & 16.1 & 24.7 & 4.28 & 18.6 \\
\hline $\mathrm{T}_{4}$ & 4.91 & 14.28 & 22.9 & 3.58 & 16.41 & 5.89 & 14.9 & 22.8 & 3.90 & 17.1 \\
\hline $\mathrm{T}_{5}$ & 5.03 & 14.10 & 22.6 & 3.50 & 16.20 & 6.04 & 14.8 & 22.8 & 3.82 & 16.8 \\
\hline $\mathrm{T}_{6}$ & 4.91 & 13.57 & 21.7 & 3.29 & 15.58 & 5.89 & 14.2 & 22.1 & 3.59 & 16.2 \\
\hline $\mathrm{T}_{7}$ & 5.04 & 13.40 & 21.4 & 3.22 & 15.39 & 6.05 & 14.1 & 21.6 & 3.51 & 15.8 \\
\hline $\mathrm{T}_{8}$ & 4.95 & 14.13 & 22.6 & 3.52 & 16.24 & 5.94 & 14.8 & 22.6 & 3.84 & 16.9 \\
\hline $\mathrm{T}_{9}$ & 4.89 & 13.03 & 20.9 & 3.07 & 15.01 & 5.87 & 13.7 & 20.9 & 3.35 & 15.6 \\
\hline $\mathrm{T}_{10}$ & 5.06 & 12.47 & 19.9 & 3.03 & 14.32 & 6.07 & 13.1 & 20.1 & 3.30 & 14.9 \\
\hline $\mathrm{T}_{11}$ & 4.55 & 12.20 & 19.5 & 2.73 & 14.01 & 5.46 & 12.8 & 19.7 & 2.98 & 14.6 \\
\hline $\mathrm{T}_{12}$ & 4.17 & 14.90 & 24.1 & 3.90 & 17.30 & 5.55 & 15.4 & 24.3 & 4.25 & 18.4 \\
\hline $\mathrm{T}_{13}$ & 4.90 & 14.27 & 22.8 & 3.57 & 16.39 & 5.88 & 15.2 & 23.0 & 3.89 & 17.2 \\
\hline $\mathrm{T}_{14}$ & 4.75 & 13.90 & 22.2 & 3.42 & 15.97 & 5.70 & 14.6 & 22.4 & 3.73 & 16.6 \\
\hline $\mathrm{T}_{15}$ & 4.50 & 13.30 & 21.3 & 3.18 & 15.28 & 5.40 & 14.0 & 21.5 & 3.47 & 15.9 \\
\hline $\mathrm{T}_{16}$ & 4.32 & 13.37 & 21.4 & 3.24 & 15.35 & 5.18 & 14.0 & 21.6 & 3.53 & 16.4 \\
\hline $\begin{array}{l}C D(p=0.05 \\
\%)\end{array}$ & 0.52 & 1.07 & 1.8 & 0.31 & 1.23 & 0.62 & 1.1 & 1.8 & 0.34 & 1.3 \\
\hline
\end{tabular}

The different nutrient management practices produced significant variation in LAl during the flowering stage. Among the nutrient application, $100 \%$ RDF through vermicompost (on equal $\mathrm{N}$ basis) produced higher LAl of 4.02 and 4.34 during both years, respectively and it was significantly comparable with 50\% RDF through FYM + 50\% RDF through poultry manure, 50\% RDF through FYM + $50 \%$ RDF through vermicompost, 50\% RDF through poultry manure $+50 \%$ RDF through tricho compost, and $1 / 4^{\text {th }} \mathrm{FYM}+1 / 4^{\text {th }}$ vermicompost $+1 / 4^{\text {th }}$ poultry manure $+1 / 4^{\text {th }}$ tricho compost. This might be due to the greater supply of nitrogen by this treatment which in turn increased leaf size, thereby resulting in maximization of LAl, light interception and high dry matter production. Application of RDF (20-40-0 NPK kg ha-1) and vermicompost @ $2 \mathrm{t} \mathrm{ha}^{-1}$, significantly increased the leaf area index in cowpea (Deepa et al., 2016).

The dry matter production (DMP) of cotton at harvest stage was significantly influenced by the different nutrient management practices studied. Among nutrient management practices, application of $100 \%$ RDF through vermicompost (on equal $\mathrm{N}$ basis) produced the highest dry biomass of 4064 and $4421 \mathrm{~kg} \mathrm{ha}^{-1}$ during both years, correspondingly and it was followed by $1 / 4^{\text {th }} \mathrm{FYM}+1 / 4^{\text {th }}$ vermicompost $+1 / 4^{\text {th }}$ Poultry Manure $+1 / 4^{\text {th }}$ tricho compost and intercropping green manure with sunnhemp and 
in situ incorporation on 50\% flowering + 50\% RDF through FYM. This might be attributed to increase in plant height, LAI and number of monopodial branches and thus in total biomass. This might be also due to its influence on photosynthesis, which could have led to accumulation of more dry matter. Romel et al. (2014) observed that combined application of MOP @ $20 \mathrm{~kg} \mathrm{ha}^{-1}$ and vermicompost @ $8 \mathrm{t} \mathrm{ha}^{-1}$ increased the dry weight of mungbean.

Table 3. Economics of different organic sources of nutrients.

\begin{tabular}{|c|c|c|c|c|c|c|c|c|}
\hline \multicolumn{5}{|c|}{ 2013-14 } & \multicolumn{4}{|c|}{ 2014-15 } \\
\hline Treatment & $\begin{array}{l}\text { Cost of cultivation } \\
\text { (Rs. ha-1) }\end{array}$ & $\begin{array}{l}\text { Gross returns } \\
\quad\left(\text { Rs. ha }{ }^{-1}\right)\end{array}$ & $\begin{array}{l}\text { Net returns } \\
(\text { Rs. ha-1) }\end{array}$ & $\begin{array}{l}\mathrm{B}: \mathrm{C} \\
\text { ratio }\end{array}$ & $\begin{array}{l}\text { Cost of cultivation } \\
\text { (Rs. ha-1) }\end{array}$ & $\begin{array}{l}\text { Gross returns } \\
\left.\text { (Rs. ha }^{-1}\right)\end{array}$ & $\begin{array}{l}\text { Net returns } \\
\left(\text { Rs. ha }{ }^{-1}\right)\end{array}$ & B:C ratio \\
\hline $\mathrm{T}_{1}$ & 33386 & 22260 & -11126 & 0.67 & 34142 & 28281 & -5861 & 0.83 \\
\hline $\mathrm{T}_{2}$ & 39386 & 34110 & -5276 & 0.87 & 40142 & 38940 & -1202 & 0.97 \\
\hline $\mathrm{T}_{3}$ & 43386 & 53520 & 10134 & 1.23 & 44142 & 61380 & 17238 & 1.39 \\
\hline $\mathrm{T}_{4}$ & 35366 & 49230 & 13864 & 1.39 & 36122 & 56430 & 20308 & 1.56 \\
\hline $\mathrm{T}_{5}$ & 37136 & 48600 & 11464 & 1.31 & 37892 & 55440 & 17548 & 1.46 \\
\hline $\mathrm{T}_{6}$ & 41386 & 46740 & 5354 & 1.13 & 42142 & 53460 & 11318 & 1.27 \\
\hline $\mathrm{T}_{7}$ & 37376 & 46170 & 8794 & 1.24 & 38132 & 52140 & 14008 & 1.37 \\
\hline $\mathrm{T}_{8}$ & 38261 & 48720 & 10459 & 1.27 & 39017 & 55770 & 16753 & 1.43 \\
\hline $\mathrm{T}_{9}$ & 39376 & 45030 & 5654 & 1.14 & 40132 & 51480 & 11348 & 1.28 \\
\hline $\mathrm{T}_{10}$ & 40261 & 42960 & 2699 & 1.07 & 41017 & 49170 & 8153 & 1.20 \\
\hline $\mathrm{T}_{11}$ & 36251 & 42030 & 5779 & 1.16 & 37007 & 48180 & 11173 & 1.30 \\
\hline $\mathrm{T}_{12}$ & 38818 & 51900 & 13082 & 1.34 & 39574 & 60720 & 21146 & 1.53 \\
\hline $\mathrm{T}_{13}$ & 38386 & 49170 & 10784 & 1.28 & 39142 & 56760 & 17618 & 1.45 \\
\hline $\mathrm{T}_{14}$ & 40386 & 47910 & 7524 & 1.19 & 41142 & 54780 & 13638 & 1.33 \\
\hline $\mathrm{T}_{15}$ & 36376 & 45840 & 9464 & 1.26 & 37132 & 52470 & 15338 & 1.41 \\
\hline $\mathrm{T}_{16}$ & 37261 & 46050 & 8789 & 1.24 & 38017 & 54120 & 16103 & 1.42 \\
\hline
\end{tabular}

The number of monopodial branches plant ${ }^{-1}$ had varied statistically between the nutrient application methods. Among the nutrient management practices, application of $100 \%$ RDF through FYM (on equal $\mathrm{N}$ basis) recorded lesser number of monopodial branches plant ${ }^{-1}$. However, this was numerically comparable with $1 / 4^{\text {th }} \mathrm{FYM}+1 / 4^{\text {th }}$ vermicompost $+1 / 4^{\text {th }}$ Poultry Manure $+1 / 4^{\text {th }}$ trichocompost. Higher number of monopodial branches plant ${ }^{-1}$ was recorded in the plot receiving nutrient by $50 \%$ RDF through FYM + 50\% RDF through poultry manure along with control.

Crop growth rate is a function of light interception by the leaf area of crop which was used to determine the crop production. The maximum crop growth rate (5.62, 3.49 and 6.49, $3.94 \mathrm{~g} \mathrm{~m}^{-2}$ day $^{-1}$ at 30- 60 DAS and 60 - 120 DAS during both years, respectively) was recorded with application of $1 / 4^{\text {th }} \mathrm{FYM}+1 / 4^{\text {th }}$ Vermicompost $+1 / 4^{\text {th }}$ Poultry Manure $+1 / 4^{\text {th }}$ Tricho during both years respectively and it was on par with application of 100\% RDF through Vermicompost (on equal $\mathrm{N}$ basis) compost. The maximum effect might be due to higher accumulation of photosynthates in various sinks which resulted in higher rate of crop growth rate. The minimum crop growth rate was recorded under control during both years.

\section{Yield and yield attributes of cotton}

Significant variation was observed between the nutrient applications with respect to number of yield and yield attributes of cotton (Table 2). Application of $100 \%$ RDF through vermicompost (on equal N basis) produced the highest number of sympodial branches plant ${ }^{-1}(15.32)$ followed by with1/4 ${ }^{\text {th }} \mathrm{FYM}$ $+1 / 4^{\text {th }}$ vermicompost $+1 / 4^{\text {th }}$ poultry manure $+1 / 4^{\text {th }}$ tricho compost. However, this was comparable with application of 100\% RDF through FYM (on equal $\mathrm{N}$ basis). The plot received no input recorded the lower values of sympodial branches plant ${ }^{-1}$. Channaveerswami (2005) reported that combined application of vermicompost @ $2.5 \mathrm{t} \mathrm{ha}^{-1}+\mathrm{RDF}$ (25:50:50 kg NPK ha-1) + copper ore tailing recorded higher number of branches (6.92) in groundnut.

The number of bolls recorded was influenced by the nutrient management practice. Application of $100 \%$ RDF through vermicompost (on equal $\mathrm{N}$ basis) produced the highest number of bolls plant $^{-1}$ and it was comparable with with $1 / 4^{\text {th }}$ FYM $+1 / 4^{\text {th }}$ vermicompost $+1 / 4^{\text {th }}$ poultry manure + $1 / 4^{\text {th }}$ trichocompost and application of $100 \%$ RDF through FYM (on equal $\mathrm{N}$ basis). This may be due to more number of sympodial branches plant ${ }^{-1}$. The boll weight was higher in the plot receiving nutrient by $100 \%$ RDF through vermicompost (on equal $\mathrm{N}$ basis) and it was comparable with with1/4 $4^{\text {th }} \mathrm{FYM}$ $+1 / 4^{\text {th }}$ vermicompost $+1 / 4^{\text {th }}$ poultry manure + $1 / 4^{\text {th }}$ tricho compost and application of $100 \%$ RDF through FYM (on equal $\mathrm{N}$ basis). The lowest boll 
weight was noticed in control plot. Ramasamy et al. (2011) observed that application of vermicompost significantly increased the kernel weight of maize.

The seed cotton yield was significantly influenced by different nutrient management practices. Among the nutrient application, 100\% RDF through vermicompost (on equal $\mathrm{N}$ basis) produced the highest seed cotton yield of 17.84 and $18.6 \mathrm{q}$ ha ${ }^{-1}$ during both years, respectively. Application of with $1 / 4^{\text {th }} \mathrm{FYM}+1 / 4^{\text {th }}$ vermicompost $+1 / 4^{\text {th }}$ poultry manure $+1 / 4^{\text {th }}$ tricho compost was found to be the next best treatment in terms of higher seed cotton yield. This was followed by $100 \%$ RDF through poultry manure (on equal $\mathrm{N}$ basis) and 50\% RDF through FYM + 50\% RDF through vermicompost. This might be due to mineralization and slow release of nutrients to cotton crop resulting in to higher uptake of nutrients with the increased seed cotton yield under vermicompost. Similar results were observed by Mohadeseh et al. (2015) in maize and Chandramohan and Chandaragiri (2007) in cotton. Hendrix et al. (1994) revealed that the higher yields in plants might be due to the fact that vermicompost supplies directly available nutrients such as nitrogen to the plants and improves the proportion of water table of the soil. Channabasanagowda et al. (2008) have also shown that the differential action of vermicompost might be because of the fact that the vermicompost has slow release of nitrogen due to slow mineralization, which helps in the availability of nutrients to the plants throughout the growth of the plant and thus resulting in higher yields. Vermicompost stimulates to influence the microbial activity of soil, increases the availability of oxygen, maintains normal soil temperature, increases soil porosity and infiltration of water, improves nutrient content and increases growth, yield and quality of the plant (Arora et al., 2011).

\section{Economics}

Economic analysis (Table 3) made in terms of gross returns, net returns, B: $\mathrm{C}$ ratio, and return per rupee invested indicated that gross returns (53520, 61380 Rs ha $^{-1}$ during both years, respectively) were higher with the application of 100\% RDF through Vermicompost (on equal $\mathrm{N}$ basis). This might be due to higher seed cotton yield compared to other treatments. Net profit (13864 and 20308 Rs ha-1 during both the years, respectively), $\mathrm{B}: \mathrm{C}$ ratio (1.39 and 1.56 during both the years, respectively were higher from cotton grown with the application of $100 \%$ RDF through Poultry Manure (on equal $\mathrm{N}$ basis) and this might be due to lower cost of cultivation compared to 100\% RDF through Vermicompost (on equal $\mathrm{N}$ basis).

\section{CONCLUSION}

From the study, it can be concluded that the addition of $100 \%$ RDF through vermicompost (on equal $\mathrm{N}$ basis) to soil enhanced the growth and yield attributes of cotton. Insitu vermicomposting may be encouraged among the farmers to meet the nutrient requirement for getting higher organic cotton cultivation yield.

\section{REFERENCES}

Alabadan, B.A., Adeoye, P. A. and E. A. Folorunso. 2009. Effects of different poultry wastes on physical, chemical and biological properties of soil. Caspian J. Environ. Sci., 7: 31-35.

Arora, V.K., Singh, C.B., Sidhu, A.S. and S.S. Thind. 2011. Irrigation, tillage and mulching effects on Soybean yield and water productivity in relation to soil texture. Agric. Water Manag., 98(4): 563-568.

Chandramohan, S. and K.K. Chandaragiri. 2007. Effect of organic manures on growth and yield attributes in cotton + blackgram intercropping system. Int. J. Plant Sci., 2: 156-160.

Channabasanagowda, N.K., Patil, B.N., Patil, J.S., Awaknavar, B.T., Ninganur. and H. Ravi. 2008. Effect of Organic Manure on Growth, Seed Yield and Quality of Wheat. Karnataka J. Agril. Sci., 21: 366-368.

Channaveerswami A.S. 2005. Studies on integrated nutrient management and planting methods on seed yield and quality of groundnut. Ph.D. Thesis, Univ. Agric. Sci., Dharwad, Karnataka (India).

Chavda, V.N. and B.S. Rajawat. 2015. Per formance evaluation of vermicompost on yield of kharif groundnut and cotton crops. Intern. J. Forestry and Crop Improvement, 6(2): 127-131.

Deepa Joshi, K.M., Gediya, J.S., Patel, M.M., Birari. and Shivangini Gupta. 2016. Effect of organic manures on growth and yield of summer cowpea [Vigna unguiculata (L.) Walp] under middle Gujarat conditions. Agric. Sci. Digest., 36(2): 134-137.

Gaur, A.C. 1991. Bulky Organic Manures and Crop Residues. In: Fertilizers, organic matter recyclable wastes and biofertilizer H.L.S Tandon, Fertilizer development and consultation Organization, New Delhi.

Kannan, P.A., Saravanan, S., Krishnakumar. and S.K. Natrajan. 2005. Biological properties of soil as influenced by different organic manure. Res. J. Agric. Biol. Sci., 1: 181-183.

Mohadeseh, V.N., Hamid, R.M. and R.G. Hamid. 2015. Effect of different levels of vermicompost on yield and quality of maize varieties. Biological Forum - An Intern. J., 7(1): 856-860.

Ramasamy, P.K., Baskar, K. and S. Ignacimuthu. 2011. Influence of vermicompost on kernel yield of Maize (Zea mays L.). Elixir Agriculture., 36: 3119-3121.

Romel Biswash, M., Wasal Rahman, M., Maksudul Haque, M., Mashuka Sharmin and Rajesh Barua. 2014. Effect of potassium and vermicompost on the growth, yield and nutrient contents of mungbean (BARI Mung 5). Open Sci. J. Biosci., and Bioeng., 1(3): 33-39. 